\title{
Towards Understanding the Students' Acceptance of MOOCs: A Unified Theory of Acceptance and Use of Technology (UTAUT)
}

\author{
https://doi.org/10.3991/ijet.v16i02.13639 \\ Maryam Altalhi \\ Taif University, Ta'if, Saudi Arabia \\ marem.metu.edu.sa
}

\begin{abstract}
Massive Open student's courses (MOOC) have stimulated the efforts made for improving the learning techniques and enhancing it the spectrum for students learning. Unfortunately, the acceptance of MOOC as a learning instrument remained low, which is perceived as an entertainment tool rather than an academic tool, particularly in developing countries. The study evaluated the student's adaptation of MOOC as an academic tool. It developed an understanding of the associated factors which impact the students' decision towards utilizing MOOC as a learning instrument. It initially investigated the constructs of the native UTAUT, subsequent to which is derived theory from the literature, amplifying the UTAUT theory scope by instigating e-learning factors associated with MOOC, such as attitude and self-efficacy. Based on the established framework, a survey was conducted where 150 MOOCs' students were recruited. The collected data were statistically analyzed using SPSS. The results showed that acceptance of the MOOCs was substantially affected by its performance expectancy, effort expectancy, social influence, self-efficiency, attitude, and facilitating conditions. It also suggested that efforts should be introduced to promote the use of MOOCs among the academic institutes in Saudi Arabia.
\end{abstract}

Keywords-Attitude, instructor, self-efficacy, technology

\section{$1 \quad$ Introduction}

MOOC is an acronym of Massive Open Online Course, a course accessible by students globally [1]. The course is free and includes video-format lectures, online assignments, quizzes, and examinations [2]. Traditionally, MOOC is defined as a learning platform that provides an opportunity for students who either lack the time or physical space to learn a subject that they feel inclined to Gao and Yang [3]. Kaplan and Haenlein [4] add that MOOC enables student to learn independently as per their schedule and pace, eliminating the parameters of place and compliance to a schedule.

The term MOOC was first heard in 2008 for explaining an open online course that the University of Manitoba in Canada [5]. MOOC is categorized into two forms, namely; xMOOCs and cMOOCs. xMOOCs is a broadcast model with similar aspects 
with the conventional courses, encompassing an instructors' predefined content, whereas, cMOOCs extracts the course material during the course [6].

In late 2012, MOOC's first major revolution was observed in the western world, with its expansion to the Middle Eastern countries in 2013. Ever since its emergence, the course enrollment is exponentially growing, evident from exceeding the number of students from 58 million in about 6850 different courses [7]. MOOC's popularity is due to its significant number of providers present in diverse regions such as Coursera, edX, Udacity in USA, FUN, Iversity in Europe, FutureLearn in the UK, while Rwaq and Edraak in the Middle East and Open2study in Australia.

In the Middle East, the MOOC platform named as Rwaq was initially commenced by Saudi Arabia in the year 2013 [8]. Rwaq is instigating efforts for gathering highquality content from qualified professionals possessing the relevant experience to improve the content quality. Curley [9] defines, "Rwaq is on its way to becoming a regional hub for e-learning in the Middle East." Macro-level advantages of MOOCs have stimulated efforts for improving the learning techniques and enhancing the spectrum for students learning. For this, MOOC offers the teacher the opportunity to connect and reach a wider audience worldwide [10]. Whereas, a reputable learning institute provide MOOC for compelling a larger audience as compared to the general online offering [10].

Current statistics revealed that MOOC students increase on an ongoing basis, such as from 2,450 to 9,400 from 2015 to 2018. Despite its popularity, MOOCs use for online education is found to be relatively low. Adham and Lundqvist [8] highlight that despite these efforts, the MOOCs' quality offered in Saudi Arabia fails to meet the quality criteria promoting the learning to seek MOOC courses. MOOC's online service also benefits the students in monetary terms as they do not have to invest in the private tutoring sessions, as a family in the region suffers from financial constraints [8]. The same study further adds that very few institutes have implemented MOOCs. Though several researches have endorsed MOOC significance in students' learning endeavors, the information related to MOOC usage promoting factors remains limited, particularly for developing countries like Saudi Arabia. Therefore, the study intends to develop and model following its empirical analysis related to MOOC adoption in the Kingdom of Saudi Arabia.

The developed model is adopted for assessing the student's acceptance of the MOOCs. Particularly, this research examines the relationships among performance expectancy, effort expectancy, social influence, facilitating conditions, self-efficacy, attitude, behavioral intention, and technology use. It also includes two demographic variables, i.e., gender and experience, for increasing their use of MOOCs. Previous researches have explored the adoption of the MOOCs concerning the eight models, including the theory of reasoned action (TRA), the technology acceptance model (TAM), the theory of planned behavior (TPB), the motivation model (MM), the model of PC utilization (MPCU), the innovation diffusion theory (IDT), the combined model (TAM/TPB), and the social cognitive theory (SCT) [11]. Similarly, the present study intends to identify the acceptance and usage of technology among students by combining the TAM and UTAUT model created by Venkatesh et al. [12]. The model explains the perceived convenience and functionality along with its acceptance and behaviors 
generated from usage. The rationale for using these models is that they provide suitable framework for reviewing and classifying the findings in the field of MOOC adoption, critically.

Griffiths et al. [13] explained that there are significant educational characteristics being compromised by MOOC, despite of the extensively growing online platforms. Further, Adham and Lundqvist [8] stated that the quality of MOOC in Saudi Arabia is not adequate, despite of growing numbers it lacks essential elements that creates the benchmarked performance and outputs in the form of students. There is need to investigate the obstacles faced in the implementation and acceptance of MOOC models among students, along with the factors that lead to the acceptance of MOOC models and its featureless implementation. Moreover, there is also need to identify the reasons of specific behavioral traits generated by students regarding MOOC. In the similar context, the current study presents a theoretical and empirical review of the factors which impact MOOC adoption, majorly focusing on the UTAUT model. Initially, the study explains the MOOC application of the acceptance models, following it, it illustrates a conceptual framework for MOOC based on the UTAUT model while expanding it by integrating different constructs. The study contributes to the existing knowledge by elucidating the behavioral intention concerning MOOCs adoption. Also, it promotes the learning institutes, educators, and scholars to further discover the MOOCs determinants in the future.

\section{$2 \quad$ Literature Review}

Researchers have adopted several models for understanding the determinants of the MOOC adoption, where the models derived from The Theory of Reasoned Action (TRA) were major. Such as the Technology Acceptance Model (TAM) [14] - [18] and the Unified Theory of Acceptance and Use of Technology (UTAUT) model [1], [19], [20].

Table 1. Studies related to MOOCs adoption

\begin{tabular}{|l|l|l|}
\hline \multicolumn{1}{|c|}{ Author (year) } & \multicolumn{1}{|c|}{ Model } & \multicolumn{1}{c|}{ Other dimensions } \\
\hline Alraimi, Zo, and Ciganek [21] & TAM & $\begin{array}{l}\text { Perceived reputation, perceived } \\
\text { openness, perceived, and user sat- } \\
\text { isfaction. }\end{array}$ \\
\hline Mulik, Srivastava, and Yajnik [19] & $\begin{array}{l}\text { TPB and self-determination theory } \\
\text { (SDT) }\end{array}$ & $\begin{array}{l}\text { Autonomous motivation and con- } \\
\text { trolled motivation }\end{array}$ \\
\hline Fianu et al. [1] & TAM and the TPB model & - \\
\hline Wu and Chen [14] & TAM, TTF and social motivation & $\begin{array}{l}\text { Task-technology fit, reputation, so- } \\
\text { cial recognition, individual-tech- } \\
\text { nology fit and openness affect. }\end{array}$ \\
\hline Yang et al. [16] & $\begin{array}{l}\text { The system quality, course quality, } \\
\text { and service quality }\end{array}$ \\
\hline Zhou [22] & DandM model and TAM & satisfaction and confirmation \\
\hline Chan et al. [18] & $\begin{array}{l}\text { Expectation confirmation model } \\
\text { ECM) }\end{array}$ & TAM \\
\hline Tarmuji et al. [17] & Perceived Resources and TAM & Perceived resource \\
\hline
\end{tabular}




\begin{tabular}{|l|l|l|}
\hline Mulik, Srivastava, and Yajnik [19] & UTAUT & Perceived value \\
\hline Fianu et al. [1] & UTAUT & $\begin{array}{l}\text { Computer self-efficacy, system } \\
\text { quality, instructional quality }\end{array}$ \\
\hline Hamdan et al. [20] & UTAUT & - \\
\hline
\end{tabular}

\subsection{Technology Acceptance Model (TAM)}

TAM model draws the interest of various researchers', particularly for empirical studies. The model addresses the student behavior towards acceptance of the digital technologies in his/her academic task [23]. In it, the TRA model is characterized into two constructs for projecting the actual behavior of the student about the technology acceptance. The acceptance is particularly studied in the context of its perceived usefulness as well as ease of using it [24].

Perceived ease towards usage studies the degree to which an individual assumes that the use of technology will require him to implement fewer efforts. Whereas the perception related to the use is the degree to which an individual assumes that using technology will enhance his performance [23]. The model withholds that both these factors are related to the students' behavior, which he/she demonstrates towards technology acceptance (Figure 1). Consequentially, the acceptable behavior of the individual determines whether the individual will carry out the actual behavior, which indicates the positive perceived ease of use and usefulness for using the technology. Additionally, the perceived ease directly impacts the perceived usefulness. External variables impact these two variables, which affect individual acceptance of the technology.

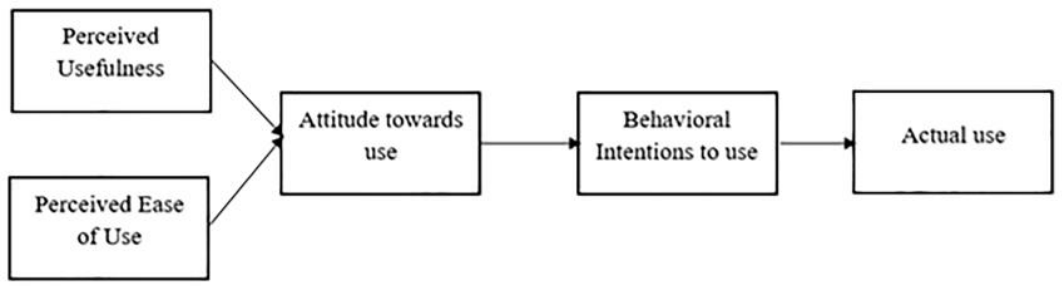

Fig. 1. TAM model [22]

\subsection{UTAUT}

Unified Theory of Acceptance and Use of Technology (UTAUT) comprise of four factors that assist in predicting the behavior intention of the individual. These factors include effort expectancy, performance expectancy, social influence, and facilitating conditions (Figure 2). Lai [25] highlights that five constructs involved in the UTATU construction, i.e., extrinsic motivation, perceived usefulness, performance expectancy, and job-fit. Venkatesh et al. [12] assert that the UTAUT model concerning technology acceptance is related to both personal and social factors. The use of UTAUT is also endorsed by Marchewka and Kostiwa [26] for predicting the behavior of the student towards technological acceptance. 


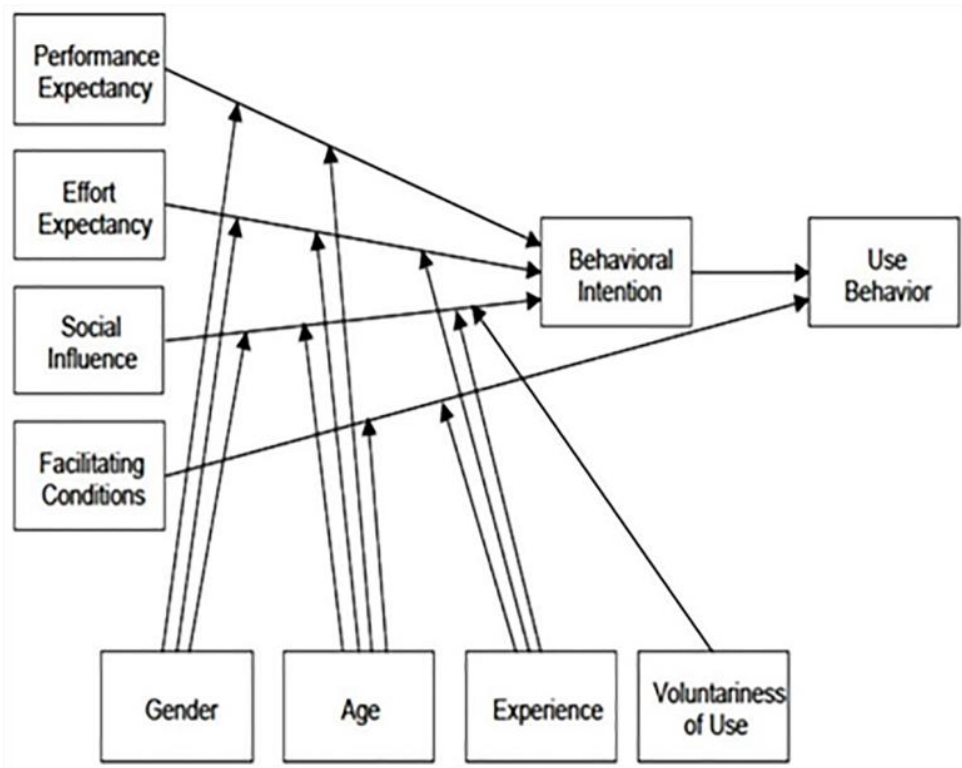

Fig. 2. UTAUT Model [12]

This paper systematically analyzed 11 studies. Based on the assessment held, the researcher derived the MOOC acceptance key factors; this includes the perceived usefulness, attitude, and social influence, tailed by performance and effort expectancy, perceived ease of use, and facility condition. Based on this, the use of the UTAUT model is found effective concerning the use of the latest technology [27], [28]. To assess students' perceptions concerning acceptable behavior. In the study, the model of UTAUT is applied. Another factor that promoted its deployment was its use in several researches [27], [28]. The earlier and existing literature find the significant relation of the model construct UTAUT. However, the researchers emphasized the need to test the model in the absence of a moderator. Though the study test circumstances are not able to highlight many likely moderators (such as the student's equal age and mandatory usage), it has used gender and students' former education status.

This section provides detail of the adoption of UTAUT as the model for instilling behavioral intention towards technology acceptance. Oh and Yoon [29] states the model effective as it considers and sets the base for trust and experience. It also endorses that the application of this model improves the intention towards usage based on effort and performance expectancy, social influence, and facilitating conditions. The integration of the two variables, i.e., experience flow and trust, improves the model predictability and amplifies its use as a model of Internet service.

Similarly, Dečman [30] highlighted the positive outcome of the UTAUT model stressing on its mandatory utilization for e-learning technology. The study indicates the social influence and performance expectancy as major impacting variables. Fianu et al. [1] research is found consistent with the model of UTAUT for MOOC acceptance, where quality improvement in terms of system and instruction were observed, along 
with self-efficacy. It demonstrated that the usage of MOOC is affected by facilitating conditions, MOOC usage, and instructional quality. Though no effect was observed for social influence and effort expectancy.

UTAUT factors are also studied by Hamdan et al. [20], who further extend it. It suggests that perception of employee-related to social influence and performance expectancy promotes his technology acceptance and enrollment in training offers through MOOC. The behavioral intention of using technology is also highlighted in Sattari, Abdekhoda, and Zarea Gavgani research [31]. According to it, performance expectancy, facilitated condition, attitude, effort expectancy, anxiety, and self-efficacy substantially influence the behavioral intention of adopting the technology. Contrary to it, the use of variables such as self-efficacy and attitude is further extended in the UTAUT model, given their effectiveness in promoting e-learning adoption.

Table 2. UTAUT related studies in e-learning

\begin{tabular}{|c|c|c|c|c|c|c|c|}
\hline \multirow[t]{2}{*}{ Author } & \multirow[t]{2}{*}{ Other dimensions } & \multirow[t]{2}{*}{ e-learning type } & \multirow[t]{2}{*}{ Adopt Au } & \multicolumn{4}{|c|}{ UTAUT } \\
\hline & & & & $P E-B I$ & $E E-B I$ & $F C-B I$ & $S I-B I$ \\
\hline $\begin{array}{l}\text { Oh and Yoon } \\
{[29]}\end{array}$ & $\begin{array}{l}\text { Trust and Flow Experi- } \\
\text { ence }\end{array}$ & e-learning' & Yes & Yes & Yes & Yes & Yes \\
\hline Dečman [30] & & e-learning system & No & Yes & No & - & Yes \\
\hline $\begin{array}{l}\text { Mulik, Sri- } \\
\text { vastava, and } \\
\text { Yajnik [19] }\end{array}$ & Perceived Value & MOOCs & & Yes & Yes & yes & Yes \\
\hline Fianu et al. [1] & $\begin{array}{l}\text { Computer Self-Effi- } \\
\text { cacy, System Quality }\end{array}$ & MOOCs & Yes & Yes & No & - & No \\
\hline $\begin{array}{l}\text { Hamdan et al. } \\
{[20]}\end{array}$ & - & MOOCs & Yes & Yes & Yes & yes & Yes \\
\hline $\begin{array}{l}\text { Tosuntas, Kara- } \\
\text { dağ, and Orhan } \\
{[32]}\end{array}$ & - & $\begin{array}{l}\text { Interactive White- } \\
\text { boards }\end{array}$ & No & Yes & Yes & Yes & Yes \\
\hline $\begin{array}{l}\text { Botero et al. } \\
\text { [33] }\end{array}$ & Attitude & M-learning & Yes & No & No & Yes & Yes \\
\hline $\begin{array}{l}\text { Sattari, Ab- } \\
\text { dekhoda, and } \\
\text { Zarea Gavgani } \\
{[31]}\end{array}$ & $\begin{array}{l}\text { Attitude, Self- } \\
\text { Efficacy, And Anxiety }\end{array}$ & $\begin{array}{l}\text { Web-based train- } \\
\text { ing (WBT) }\end{array}$ & Yes & Yes & yes & yes & No \\
\hline Al-Shehri [34] & - & $\begin{array}{l}\text { Desire2Learn } \\
\text { (D2L) }\end{array}$ & Yes & Yes & Yes & Yes & Yes \\
\hline $\begin{array}{l}\text { Mikalef, Pap- } \\
\text { pas, and Gian- } \\
\text { nakos [35] }\end{array}$ & $\begin{array}{l}\text { Computer Self- } \\
\text { Efficacy }\end{array}$ & $\begin{array}{l}\text { Video-based learn- } \\
\text { ing (VBL) }\end{array}$ & No & Yes & No & - & No \\
\hline $\begin{array}{l}\text { Lwoga and } \\
\text { Komba [36] }\end{array}$ & $\begin{array}{l}\text { Computer Self- } \\
\text { Efficacy }\end{array}$ & $\begin{array}{l}\text { Web-based learn- } \\
\text { ing management } \\
\text { systems (LMS) }\end{array}$ & Yes & Yes & yes & - & Yes \\
\hline
\end{tabular}

\subsection{Performance expectancy}

Venkatesh et al. [12] indicate that individual adopts a system based on his perception of how will it help improve his/her performance. The base of performance expectancy is formulated on the similarities which are found in the construct of various models, 
i.e., in TAM and TAM 2, perceived usefulness, in motivational model, extrinsic motivation, while in the personal computer utilization model job fit, whereas for the innovation diffusion theory it is relative advantage, and for social cognitive theory, the variable is expectations towards outcome. UTAUT model proposes a direct effect of the behavioral intention on performance expectancy concerning the adoption of the technology. Additionally, several studies identified the effectiveness of this construct in instilling technology adoption for a user [29], [30] - [32], [34] - [37], particularly for MOOCs $[1,19,20]$. In line with the theory, the study suggests:

H1: There is a significant impact of performance expectancy on students' behavioral intentions to use MOOCs.

\subsection{Effort expectancy}

The term effort expectancy is regarded as the degree of ease related to the utilization of the system [12]. The formation of the expert expectancy is based on the similarity which prevails among the constructs belonging to various models such as perceived ease of use, complexity, and ease of use derived from TAM, MPCU, and the innovation diffusion theory. UTAUT model proposed a direct influence of the behavioral intention towards the performance expectancy concerning the adoption of the technology. This is consistent with the earlier findings which supplement its use in the e-learning contexts [29], [31], [32], [34], [36], [37]. In correspondence to the theory, the research posits:

H2: There is a significant impact of effort expectancy on students' behavioral intentions to use MOOCs.

\subsection{Social influence}

Social influence is related to the degree of importance an individual perceives from others, who promote him towards the use of the introduced system. This influence is system-based and can be application-based, while the subjective norms in it are related to the non-system and non-specific behavior [12]. Various theories pointed towards the formation of social influence as an outcome of the subjective norms, such as these is drawn from the innovation diffusion theory variable of the image and the MPCU.

UTAUT model states a direct influence of the behavioral intention towards the performance expectancy concerning the adoption of the technology. This is consistent with the earlier findings which supplement its use in the e-learning contexts [29], [31], [32], [34], [36], [37]. In correspondence to the theory, the study posits:

H3: There is a significant impact of social influence on students' behavioral intentions to use MOOCs.

\subsection{Facilitating condition}

The facilitating conditions are said to be directly linked to the usage of the system, as highlighted in various theories. The concept of the facilitating condition is regarded 
as an individuals' conviction about the perception of organizational and technical infrastructure for supplementing the system [12]. The main constructs involved in the facilitating conditions encompass perceived behavioral control that is founded on the TRA and the TPB, facilitating conditions that are derived from MPCU and compatibility, which is extracted from the innovation diffusion theory.

UTAUT model proposes a direct influence of the behavioral intention towards the performance expectancy concerning technology adoption. This is in-line with previous findings that support its use in the e-learning contexts [29], [31], [32], [34], [36], [37]. In correspondence to the theory, the study posits:

H4: There is a significant relationship between facilitating conditions (FC) and behavioral intention.

\subsection{Computer self-efficacy}

Self-efficacy is the ability of the individuals to decide on a task [38]. Reflecting upon the computer science literature, computer self-efficacy is the individual capability to apply the computer skills for executing or completing a task [35]. Several studies in the e-learning context endorsed the variable of computer self-efficacy as an integral part of promoting students' adoption of MOOCs [31], [36]. These findings contribute to the extension of the UTAUT model related to the construct of computer self-efficacy. Based on it, the study posits that:

H5: There is a significant relationship between computer self-efficacy and students' behavioral intentions to use MOOCs.

\subsection{Attitude and MOOCs}

The literature suggests that attitude substantially impacts an individual's preparedness, acceptance, and individual behavior to use technology [39] - [41]. Such as if an individual's attitude is positive concerning the technology use, he/she is likely to integrate it into his/her learning. Hussein [39] demonstrates attitude as a prime contributor for promoting students to use e-learning. Ozdamli and Uzunboylu [42] advocate that students' intention, as well as perception to use e-learning, is dependent on his/her attitude towards technology. Budu, Yinping, and Mireku [43] show that student's participation and attitude share a significant relationship concerning the successful use and implementation of E-learning. Despite using advanced technology infrastructure, the learning-process potential would not be achieved if students do not hold a positive attitude towards it [41]. Based on it, the study posits that:

H6: There is a significant relationship between attitude and students' behavioral intentions to use MOOCs.

\subsection{Behavioral intention and MOOCs}

Anecdotal studies found on the model of UTAUT, such as Venkatesh et al. [12], highlighted $26 \%$ changes in the behavioral intention. Botero et al. [33] have extended the UTAUT model by integrating attitude in the model, which changes the behavioral 
intention of up to $54 \%$. These studies illuminate the need to integrate the attitude variable in the model for improving its explanation capacity. Doing this, the model can increase the acceptable behavior towards MOOCs in the context of e-learning [31], [33]. Several studies support its effectiveness for improving the acceptance of the technology [14], [17] - [19]. Inline to the theory, the study posits:

H7: There is a significant relationship between behavioral intention and students' MOOC usage.

\subsection{Usage behavior}

The usage behavior is also reflected in the original TRA model. Reflecting upon the development of the TAM framework, Davis, Bagozzi, and Warshaw [23] proposed the generalizability of the TRA model for examining the myriad of human behaviors. The wide range of behavior makes it's appropriate for investigating the determinants in a special case, such as behavior for using a computer. Like the behavioral intentions, the application of the behavioral usage was not defined explicitly in the UTAUT model development, despite it being weighed via system logs. The study uses the UTAUT model and assimilates in various variables, as first suggested by Venkatesh et al. [12]. Figure 3 represents the research model on which the hypotheses have been formulated.

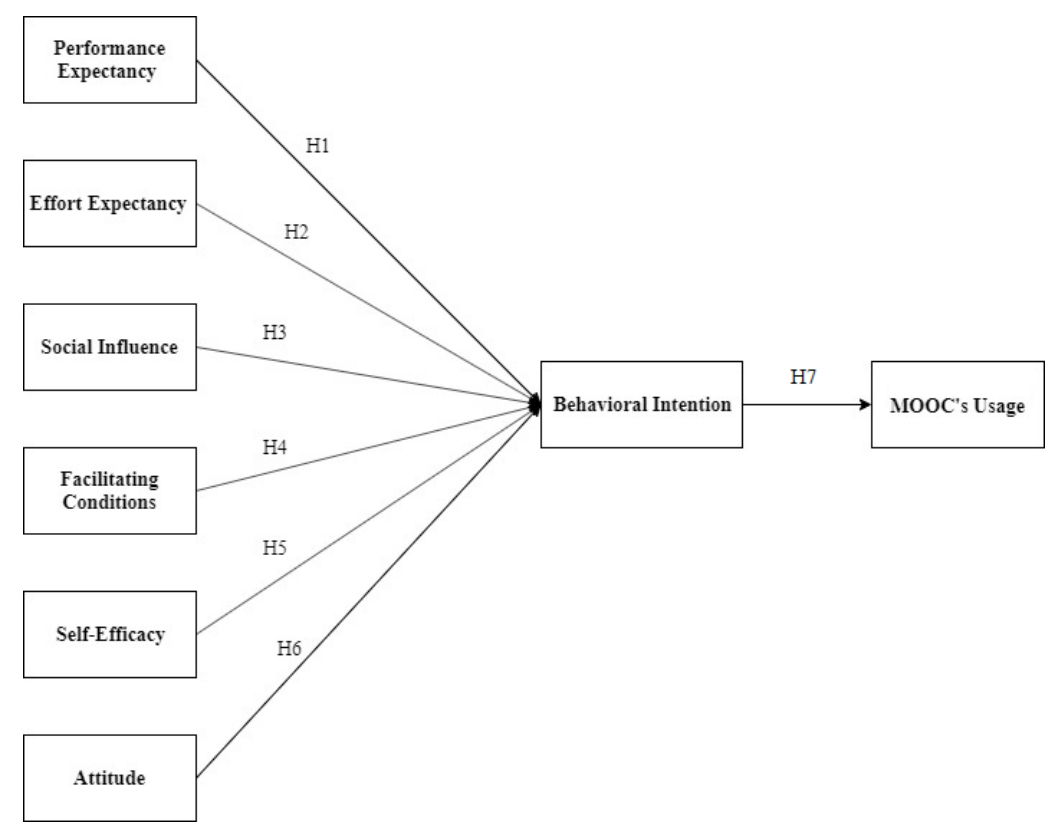

Fig. 3. Research model 


\section{Methods}

\subsection{Study design}

A descriptive study design is used for the analysis of the understanding of the students' acceptance of MOOCs. A quantitative approach is implied as it helps to quantify the study results [44].

\subsection{Study sample}

The sample consists of the students who have attended Massive Open Online Courses (MOOC) such as Coursera, Udacity, EdX, and NPTEL. One hundred and seventy students were recruited using random sampling technique. The rationale for selecting this technique helps to generalize the study findings.

\subsection{Data collection}

The data were collected through a self-administered questionnaire, both online and offline. It consisted of two parts; one demographics, while the second was related to the key constructs in the research. The online questionnaire was shared on the different social media platform groups related to MOOCs following a university survey. The compiled and completed questionnaires were included, while incomplete questionnaires were excluded, leading to a remaining questionnaire of 150.

\subsection{Data analysis}

The data were analyzed using IBM SPSS (Statistical Package for Social Sciences) Version 23.0. Descriptive statistics were used for categorical variables while the advanced statistical tests for continuous variables (correlation and multiple regression analysis).

\section{$4 \quad$ Results}

Table 3 presents the demographic analysis of the participants. It shows that most of the participants were male, i.e., 123, whereas the number of females was 27 . The age analysis shows that the majority were aged 22 to 23 years $(n=102)$, following the age group of 23 to 25 years $(n=36)$ and remaining above 25 years $(n=12)$. The educational analysis shows that the majority were undergraduates $(n=99)$, following graduates $(n=39)$, and postgraduate students $(n=12)$. The computer knowledge was analyzed, which showed that the majority had good computer literacy $(n=86)$, followed by internet usage $(n=89)$, and the use of MOOC's experience was found to be less than one year $(n=67)$. 
Paper-Towards Understanding the Students' Acceptance of MOOCs: A Unified Theory...

Table 3. Participants demographics

\begin{tabular}{|c|c|c|}
\hline Variable & & Frequency $(\mathbf{N})$ \\
\hline \multicolumn{3}{|l|}{ Gender } \\
\hline & Male & 123 \\
\hline & Female & 27 \\
\hline \multicolumn{3}{|l|}{ Age } \\
\hline & 18 to 22 years & 102 \\
\hline & 23 to 25 years & 36 \\
\hline & Above 25 years & 12 \\
\hline \multicolumn{3}{|l|}{ Education } \\
\hline & Undergraduates & 99 \\
\hline & Graduates & 39 \\
\hline & Post Graduates & 12 \\
\hline \multicolumn{3}{|l|}{ Computer Literary } \\
\hline & Low & 36 \\
\hline & Good & 86 \\
\hline & Excellent & 26 \\
\hline \multicolumn{3}{|l|}{ Internet Usage } \\
\hline & Rare & 12 \\
\hline & Medium & 89 \\
\hline & Frequent & 49 \\
\hline \multicolumn{3}{|l|}{ MOOC experience } \\
\hline & Below one year & 67 \\
\hline & One to three years & 49 \\
\hline & Four to six years & 26 \\
\hline & Above six years & 8 \\
\hline
\end{tabular}

Table 4 demonstrates the correlation between the participant's behavioral intention and different study constructs. It shows that correlation among the study variables is high as the significance value for most of the study variables had a p-value below 0.05 . 
Table 4. Correlation between the study constructs

\begin{tabular}{|l|l|c|c|c|c|c|c|c|}
\hline \multicolumn{2}{|c}{} & BI & PE & EE & SI & FC & SC & A \\
\hline \multirow{3}{*}{ Behavioral Intention } & Pearson Correlation & 1 & .091 & .013 & .074 & -.089 & -.112 & -.113 \\
\cline { 2 - 10 } & Sig. (2-tailed) & & 0.013 & 0.053 & 0.034 & 0.046 & .019 & 0.036 \\
\hline \multirow{2}{*}{ Performance Expectancy } & Pearson Correlation & -.034 & 1 & .090 & .010 & .079 & -.099 & \\
\cline { 2 - 10 } & Sig. (2-tailed) & .748 & & 0.013 & 0.048 & 0.034 & 0.666 & .029 \\
\hline Effort Expectancy & Pearson Correlation & -.002 & .090 & 1 & $.494^{* *}$ & $.481^{* *}$ & $.435^{* *}$ & \\
\cline { 2 - 10 } & Sig. (2-tailed) & 0.053 & 0.013 & & .000 & .000 & .000 & .010 \\
\hline Social Influence & Pearson Correlation & -.001 & .010 & $.494^{* *}$ & 1 & $.535^{* *}$ & $.469^{* * *}$ & \\
\cline { 2 - 10 } & Sig. (2-tailed) & 0.034 & 0.058 & .000 & & .000 & .000 & .012 \\
\hline Facilitating Conditions & Pearson Correlation & -.015 & .079 & $.481^{* *}$ & $.535^{* *}$ & 1 & $.556^{* *}$ & \\
\cline { 2 - 10 } & Sig. (2-tailed) & 0.046 & 0.034 & .000 & .000 & & .000 & .324 \\
\hline Self-Efficacy & Pearson Correlation & -.032 & -.099 & $.435^{* *}$ & $.469^{* *}$ & $.556^{* *}$ & 1 & \\
\cline { 2 - 10 } & Sig. (2-tailed) & .019 & 0.666 & .000 & .000 & .000 & & .0432 \\
\hline Attitude & Pearson Correlation & -.011 & -.112 & $.476^{* *}$ & $.603^{* *}$ & $.526^{* *}$ & $.710^{* *}$ & 1 \\
\hline & Sig. (2-tailed) & 0.034 & .029 & .010 & .012 & .214 & .0432 & \\
\hline
\end{tabular}

Correlation is significant at the 0.01 level (2-tailed).

Table 5 shows the regression analysis findings of the students' responses. The responses showed that usage behavior was substantially affected by performance expectancy (p-value 0.001) of the participants along with effort expectancy (p-value 0.003), social influence ( $p$-value 0.003 ), facilitating conditions ( $p$-value 0.013 ), and self-efficacy (p-value 0.013). Similar were the results for the impact of attitude on the usage behavior of the students (p-value 0.02).

Table 5. Regression analysis

\begin{tabular}{|c|c|c|c|c|c|c|}
\hline \multirow{2}{*}{\multicolumn{2}{|c|}{ Model }} & \multicolumn{2}{|c|}{$\begin{array}{l}\text { Unstandardized } \\
\text { Coefficients }\end{array}$} & \multirow{2}{*}{$\begin{array}{c}\begin{array}{c}\text { Unstandardized } \\
\text { Coefficients }\end{array} \\
\text { Beta }\end{array}$} & \multirow[t]{2}{*}{$\mathbf{t}$} & \multirow[t]{2}{*}{ Sig. } \\
\hline & & $\boldsymbol{B}$ & Std. Error & & & \\
\hline \multirow[t]{7}{*}{1} & (Constant) & .940 & .342 & & 2.746 & .004 \\
\hline & Performance expectancy & .119 & .031 & .203 & 3.809 & .001 \\
\hline & Effort expectancy & .084 & .026 & .159 & 3.181 & .003 \\
\hline & Social Influence & .065 & .024 & .102 & 2.813 & .003 \\
\hline & Facilitating Conditions & .063 & .023 & .261 & 5.580 & .013 \\
\hline & Self-Efficacy & .106 & .014 & .263 & 5.540 & .013 \\
\hline & Attitude & .083 & .024 & .159 & 3.173 & .002 \\
\hline
\end{tabular}

\section{Discussion}

The study contributes to the literature central on the acceptance of MOOC by supplying in a context-specific conceptual framework, which may affect the intention of the higher education students towards adopting MOOC as the learning tool. The study has developed the framework by applying the UTAUT theory, which is recognized as one of the utmost parsimonious behavioral theories. The correlation results validate the study hypothesis showing that there is a substantial impact of study constructs with behavioral intention. 
The results are consistent with the previous finding, which shows that usage and behavioral intention are substantially related to each other [45]. The usage is impacted due to different study variables and conditions of the individuals [45]. The provided model application is assumed to help in adopting MOOC as technology. Also, university administration can provide guidelines that help promote acceptance among teachers and students. Understanding of the student adaptation is also crucial for delivering better results and acceptance of MOOCs. Primarily, the two drivers observed include performance expectancy and social influence. There is change in the education of students and development of professional skills as the result of rapid evolution of MOOCs in the recent years [46]. Therefore, there is need of multimedia MOOC teaching system for computer application course in vocational college as experimental subject [47].

The students interested in learning are likely to be provided with accessible, flexible, affordable and fast-track completion of university courses through MOOCs [48]. The current study results are also endorsed by Mulik, Srivastava, and Yajnik [19], which showed that the intention of using MOOC increased due to facilitating conditions, social influence, and effort and performance expectancy. It suggests that the merits of MOOCs technology should be promoted and communicated. University administrators should also promote the positive effect of MOOCs. This can be done by inviting experienced practitioners and successful students who share their successful MOOC experiences for motivating individuals to adopt MOOC. Similarly, different short videos can be used for demonstrating the benefits linked to MOOCs usage for staff and teachers. The academic institutions must formulate a group for answering students' queries related to MOOCs usage. Accordingly, different seminars could be arranged for the students where different materials, benefits, and optimum use of MOOC can be communicated.

\section{Conclusion}

The study developed and tested the integrated model of TAM and UTAUT for technology acceptance among students. The study findings suggest that teachers should instigate efforts to improve the students' perception concerning the performance expectancy and social influence for MOOCs adaptation. The results further direct future researches to explore how students define success on a personal level. They must also explore how MOOC assists students in their learning while analyzing the factors that promote their engagement. It also suggests using the developed framework for identifying the unknown variables that might affect the use of MOOCs among the participants.

\section{Acknowledgement}

This study was financially supported via a funding grant by Deanship of Scientific Research, Taif University Researchers Supporting Project number. TURSP-2020 / 300), Taif University, Taif, Saudi Arabia). 


\section{$8 \quad$ References}

[1] E. Fianu, C. Blewett, G. Ampong, and K. Ofori, "Factors affecting MOOC usage by students in selected Ghanaian universities," Education Sciences, vol. 8, no. 2, p. 70, May, 2018. https://doi.org/10.3390/educsci8020070

[2] P. O'Prey, Massive Open Online Courses: Higher Education's Digital Moment. Universities UK, 2013. [E-book] Available: https://www.universitiesuk.ac.uk/policy-and-analysis/reports/Documents/2013/massive-open-online-courses.pdf. https://doi.org/10.1136/bmj. $\underline{\mathrm{f} 3201}$

[3] S. Gao and Y. Yang, "Exploring users' adoption of MOOCs from the perspective of the institutional theory," In WHICEB 2015 Proceedings 26, 2015, pp. 282-290.

[4] A. M. Kaplan and M. Haenlein, "Higher education and the digital revolution: About MOOCs, SPOCs, social media, and the Cookie Monster," Business Horizons, vol. 59, no. 4, pp. 441-450, Jul., 2016. https://doi.org/10.1016/j.bushor.2016.03.008

[5] T. R. Liyanagunawardena, A. A. Adams, and S. A. Williams, "MOOCs: A systematic study of the published literature 2008-2012," The International Review of Research in Open and Distributed Learning, vol. 14, no. 3, p. 202, Jul., 2013. https://doi.org/10.19173/irrodl.v14i3. $\underline{1455}$

[6] K. F. Hew and W. S. Cheung, "Students' and instructors' use of massive open online courses (MOOCs): Motivations and challenges," Educational Research Review, vol. 12, pp. 4558, Jun., 2014. https://doi.org/10.1016/j.edurev.2014.05.001

[7] J. Chauhan, "An overview of MOOC in India," International Journal of Computer Trends and Technology, vol. 49, no. 2, pp. 111-120, Jul., 2017.

[8] R. S. Adham and K. O. Lundqvist, "MOOCS as a method of distance education in the Arab world - A review paper," European Journal of Open, Distance and E-Learning, vol. 18, no. 1, pp. 123-138, Jul., 2015. https://doi.org/10.1515/eurodl-2015-0009

[9] N. Curley, "Saudi Arabia's Rwaq builds an online courseware platform for Middle East," 2013. Available: http://www.wamda.com/2013/12/saudi-arabiarwaq-online-coursewaremooc-middle-east

[10] C. Alario-Hoyos, M. Perez-Sanagustin, C. Delgado-Kloos, H. A. Parada G, and M. MunozOrganero, "Delving into participants' profiles and use of social tools in MOOCs," IEEE Transactions on Learning Technologies, vol. 7, no. 3, pp. 260-266, Jul., 2014. https://doi. org/10.1109/tlt.2014.2311807

[11] P. B. GovindAarajan and A. R. Krishnan, "A study on influence of web quality and self efficacy on massive open online courses (MOOCs) technology adoption by extending the Utaut model with reference to student MOOC users," Shanlax International Journal of Management, vol. 7, no. 2, pp. 47-53, Oct., 2019. https://doi.org/10.34293/management.v7i2.820

[12] V. Venkatesh, M.G. Morris, G. B. Davis, and F. D. Davis, "User acceptance of information technology: Toward a unified view," MIS Quarterly, vol. 27, no. 3, p. 425, 2003. https://doi. org/10.2307/30036540

[13] R. Griffiths, C. Mulhern, R. Spies, and M. Chingos, "Adopting MOOCS on campus: A collaborative effort to test MOOCS on campuses of the university system of Maryland," Online Learning, vol. 19, no. 2, p. 2, 2015. https://doi.org/10.24059/olj.v19i2.523

[14] B. Wu and X. Chen, "Continuance intention to use MOOCs: Integrating the technology acceptance model (TAM) and task technology fit (TTF) model," Computers in Human Behavior, vol. 67, pp. 221-232, Feb., 2017. https://doi.org/10.1016/j.chb.2016.10.028

[15] H.-H. Yang and C.-H. Su, "Learner behaviour in a MOOC practice-oriented course: In empirical study integrating TAM and TPB," The International Review of Research in Open and 
Distributed Learning, vol. 18, no. 5, pp. 35-63, Aug., 2017. https://doi.org/10.19173/irrodl.v18i5.2991

[16] M. Yang, Z. Shao, Q. Liu, and C. Liu, "Understanding the quality factors that influence the continuance intention of students toward participation in MOOCs," Educational Technology Research and Development, vol. 65, no. 5, pp. 1195-1214, Feb., 2017. https://doi.org/ $\underline{10.1007 / \mathrm{s} 11423-017-9513-6}$

[17] N. H. Tarmuji, A. A. Nassir, S. Ahmad, N. M. Abdullah, and A. S. Idris, "Students' acceptance of e-learning in mathematics: Comparison between LMS and MOOC using SEM PLS approach,” AIP Conference Proceedings, vol. 1974, no. 1, p. 050008, 2018. https://doi. org/10.1063/1.5041708

[18] M. M. Chan, M. De la Roca, R. B. Plata, A. M. Merodio, and H. A. Salvatierra, "Analyzing the effectiveness of using enhanced activities with simulation software in a Mooc," In EDULEARN19 Proceedings, 2019. https://doi.org/10.21125/edulearn.2019.1058

[19] S. Mulik, M. Srivastava, and N. Yajnik, "Extending the UTAUT model to examine MOOC adoption," NMIMS Management Review, vol. 36, pp. 26-44, 2018.

[20] F. Hamdan, N. Nordin, F. Khalid, M. S. Muslimin, and H. Norman, "Technology acceptance of online managerial finance training via massive open online courses for lifelong learning," Advanced Science Letters, vol. 24, no. 4, pp. 2365-2369, Apr., 2018. https://doi. org/10.1166/asl.2018.10955

[21] K. M. Alraimi, H. Zo, and A. P. Ciganek, "Understanding the MOOCs continuance: The role of openness and reputation," Computers \& Education, vol. 80, pp. 28-38, Jan., 2015. https://doi.org/10.1016/j.compedu.2014.08.006

[22] J. Zhou, "Exploring the factors affecting learners' continuance intention of MOOCs for online collaborative learning: An extended ECM perspective," Australasian Journal of Educational Technology, vol. 33, no. 5, Apr., 2017. https://doi.org/10.14742/ajet.2914

[23] F. D. Davis, R. P. Bagozzi, and P. R. Warshaw, "User acceptance of computer technology: A comparison of two theoretical models," Management Science, vol. 35, no. 8, pp. 982 1003, Aug., 1989. https://doi.org/10.1287/mnsc.35.8.982

[24] V. Venkatesh and H. Bala, "Technology acceptance model 3 and a research agenda on interventions," Decision Sciences, vol. 39, no. 2, pp. 273-315, May, 2008. https://doi.org/ 10.1111/j.1540-5915.2008.00192.x

[25] P. Lai, "The literature review of technology adoption models and theories for the novelty technology," Journal of Information Systems and Technology Management, vol. 14, no. 1, Apr., 2017.

[26] J. T. Marchewka and K. Kostiwa, "An application of the UTAUT model for understanding student perceptions using course management software," Communications of the IIMA, vol. 7, p. 10, 2007.

[27] Y. K. Dwivedi, N. P. Rana, H. Chen, and M. D. Williams, "A meta-analysis of the Unified Theory of Acceptance and Use of Technology (UTAUT)," IFIP Advances in Information and Communication Technology, pp. 155-170, 2011. https://doi.org/10.1007/978-3-64224148-2 10

[28] A. A. Taiwo, A. K. Mahmood, and A. G. Downe, "User acceptance of eGovernment: Integrating risk and trust dimensions with UTAUT model," 2012 International Conference on Computer \& Information Science (ICCIS), 2012. https://doi.org/10.1109/iccisci.2012.629 $\underline{7222}$

[29] J.-C. Oh and S.-J. Yoon, "Predicting the use of online information services based on a modified UTAUT model," Behaviour \& Information Technology, vol. 33, no. 7, pp. 716-729, Apr., 2014. https://doi.org/10.1080/0144929x.2013.872187 
[30] M. Dečman, "Modeling the acceptance of e-learning in mandatory environments of higher education: The influence of previous education and gender," Computers in Human Behavior, vol. 49, pp. 272-281, Aug., 2015. https://doi.org/10.1016/j.chb.2015.03.022

[31] A. Sattari, M. Abdekhoda, and V. Zarea Gavgani, "Determinant factors affecting the webbased training acceptance by health students, applying UTAUT model," International Journal of Emerging Technologies in Learning (iJET), vol. 12, no. 10, p. 112, Nov., 2017. https://doi.org/10.3991/ijet.v12i10.7258

[32] Ş. B. Tosuntaş, E. Karadağ, and S. Orhan, "The factors affecting acceptance and use of interactive whiteboard within the scope of FATIH project: A structural equation model based on the Unified Theory of acceptance and use of technology," Computers \& Education, vol. 81, pp. 169-178, Feb., 2015. https://doi.org/10.1016/j.compedu.2014.10.009

[33] G. García Botero, F. Questier, S. Cincinnato, T. He, and C. Zhu, "Acceptance and usage of mobile assisted language learning by higher education students," Journal of Computing in Higher Education, vol. 30, no. 3, pp. 426-451, Mar., 2018. https://doi.org/10.1007/s12528$\underline{018-9177-1}$

[34] M. Al-Shehri, "The effectiveness of D2L system: An evaluation of teaching-learning process in the Kingdom of Saudi Arabia," International Journal of Advanced Computer Science and Applications, vol. 8, no. 1, 2017. https://doi.org/10.14569/ijacsa.2017.080156

[35] P. Mikalef, I. O. Pappas, and M. Giannakos, "An integrative adoption model of video-based learning," International Journal of Information and Learning Technology, vol. 33, no. 4, pp. 219-235, Aug., 2016. https://doi.org/10.1108/ijilt-01-2016-0007

[36] E. T. Lwoga and M. Komba, "Antecedents of continued usage intentions of web-based learning management system in Tanzania," Education + Training, vol. 57, no. 7, pp. 738-756, Sep., 2015. https://doi.org/10.1108/et-02-2014-0014

[37] N. G. Uğur and A. H. Turan, "E-learning adoption of academicians: A proposal for an extended model," Behaviour \& Information Technology, vol. 37, no. 4, pp. 393-405, Feb., 2018. https://doi.org/10.1080/0144929x.2018.1437219

[38] A. Bandura, "Self-efficacy mechanism in human agency," American Psychologist, vol. 37, no. 2, pp. 122-147, 1982. https://doi.org/10.1037/0003-066x.37.2.122

[39] Z. Hussein, "Leading to intention: The role of attitude in relation to technology acceptance model in e-learning," Procedia Computer Science, vol. 105, pp. 159-164, 2017. https://doi. org/10.1016/j.procs.2017.01.196

[40] P. L. Phua, S. L. Wong, and R. Abu, "Factors influencing the behavioural intention to use the internet as a teaching-learning tool in home economics," Procedia - Social and Behavioral Sciences, vol. 59, pp. 180-187, Oct., 2012. https://doi.org/10.1016/j.sbspro.2012.09.263

[41] F. Weng, R.-J. Yang, H.-J. Ho, and H.-M. Su, "A TAM-based study of the attitude towards use intention of multimedia among school teachers," Applied System Innovation, vol. 1, no. 3, p. 36, Sep., 2018. https://doi.org/10.3390/asi1030036

[42] F. Ozdamli and H. Uzunboylu, "M-learning adequacy and perceptions of students and teachers in secondary schools," British Journal of Educational Technology, vol. 46, no. 1, pp. 159-172, Jan., 2014.

[43] K. W. A. Budu, M. Yinping, and K. K. Mireku, "Investigating the effect of behavioral intention on e-learning systems usage: Empirical study on tertiary education institutions in Ghana," Mediterranean Journal of Social Sciences, vol. 9, no. 3, pp. 201-216, May, 2018. https://doi.org/10.2478/mjss-2018-0062

[44] J. W. Creswell and J. D. Creswell, Research Design: Qualitative, Quantitative, and Mixed Methods Approaches. Thousand Oaks, CA: Sage Publications, 2017. https://doi.org/10. 5539/elt.v12n5p40 
[45] G. A. G. Mendoza, I. Jung, and S. Kobayashi, "A review of empirical studies on MOOC adoption: Applying the unified theory of acceptance and use of technology," International Journal for Educational Media and Technology, vol. 11, pp. 15-24, 2017.

[46] R. Alcarria, B. Bordel, D. Martín de Andrés, and T. Robles, "Enhanced peer assessment in MOOC evaluation through assignment and review analysis," International Journal of Emerging Technologies in Learning (iJET), vol. 13, no. 1, p. 206, Jan., 2018. https://doi. org/10.3991/ijet.v13i01.7461

[47] Z. Ji, "Application and empirical investigation of new MOOC teaching system in computer application course," International Journal of Emerging Technologies in Learning (iJET), vol. 11, no. 5, p. 62, May, 2016. https://doi.org/10.3991/ijet.v11i05.5696

[48] R. Gupta and N. Sambyal, "An understanding approach towards MOOCs," International Journal of Emerging Technology and Advanced Engineering, vol. 3, pp. 312-315, 2013.

\section{$9 \quad$ Author}

Dr. Maryam Altalhi works in the Department of Management Information System College of Business Administration, Taif University, Saudi Arabia. She completed her $\mathrm{PhD}$ of Information Systems from University Technology Malaysia, Malaysia in 2017. She also holds a Master of Management Information System, La Trobe University, Australia (2013) and Bachelor of Computer Science, Taif University, Saudi Arabia (2006)

Dr. Maryam Muti Altalhi has many publications in reputable journals, has also successfully produced, and published conference papers.

Article submitted 2020-02-07. Resubmitted 2020-09-16. Final acceptance 2020-09-17. Final version published as submitted by the authors. 